\title{
PENGARUH PENAMPILAN KANDIDAT TERHADAP EVALUASI KANDIDAT OLEH PEMILIH (Studi Eksperimental Penggunaan Jilbab oleh Caleg Perempuan)
}

\author{
Rani Prita Prabawangi \\ Prodi Pendidikan Pancasila dan Kewarganegaraan Universitas Negeri Malang \\ E-mail: prabawangi@gmail.com
}

\begin{abstract}
In legislative elections, it's so common that voter went to polling station without having decision to whom would he gave his trust to be his representative. In fact, it's not even uncommon that when they looked at the photos of those who ran in the polls, it was the first time for the voters saw their faces. Under this conditions, where the level of information's very low, simple cues such as the appearance of the candidate, candidates degree, party affiliation, and others became sources of voters argument making. This study's about the perception that came to voters mind when they saw a photograph of the candidate. It focused to see the effect of candidate appearance, in this case : the use of the veil and not, to the candidate evaluation by voters. It questioned did certain forms of appearance such as the wearing of a veil, made the wearer considered better than the one without. One of the most interesting finding of this study was that women candidates who wore veils were not considered more religious or more honest than the other candidates who didn't.
\end{abstract}

Keywords: candidates appearance; low information voters; NFC; candidate evaluation

\begin{abstract}
Abstrak:Pada Pemilu legislatif, seringkali seorang pemilih mendatangi TPS tanpa memiliki pilihan mengenai siapa yang akan dia pilih untuk menjadi wakilnya di daerah dan pusat, karena minimnya pengetahuan mereka akan pilihan yang mereka miliki. Bahkan tak jarang ketika melihat foto-foto dari mereka yang mencalonkan diri di TPS, itu adalah kali pertama melihat wajah calon wakil mereka. Dalam kondisi di mana tingkat informasi sangat rendah ini, petunjuk-petunjuk sederhana seperti penampilan kandidat, gelar, afiliasi partai, dan lain-lain menjadi sumber penyusunan argumen bagi pemilih.Studi ini adalah studi mengenai persepsi yang muncul di benak pemilih saat melihat foto kandidat. Fokus dari studi ini, melihat pengaruh penampilan kandidat dalam hal ini penggunaan jilbab dan tidak terhadap evaluasi kandidat oleh pemilih. Apakah bentuk penampilan tertentu seperti pemakaian jilbab, membuat pemakainya dinilai lebih baik dari yang tidak menggunakan. Hasil uji komparatif menunjukkanbahwa kandidat wanita yang menggunakan jilbab tidak dinilai lebih religius ataupun lebih jujur dibanding kandidat yang lain.
\end{abstract}

Kata kunci: penampilan kandidat, low information voters, NFC; evaluasi kandidat

Teori-teori tentang demokrasi mengidealkan masyarakat atau pemilih yang berpengetahuan politik, sehingga dapat memutuskan pilihannya berdasarkan hasil evaluasi kognitif mengenai kualitas kandidat yang didasarkan pada isu yang diangkat, rekam jejak, serta hal-hal lain yang mengindikasikan kemampuan kandidat tersebut. Namun pada kenyataannya, karena berbagai alasan, informasi mengenai politik menjadi cukup mahal sehingga masyarakat tidak jarang menempuh jalan singkat untuk memperoleh informasi yang dirasa cukup sebagai dasar pilihannya.
Beberapa isyarat atau petunjuk sederhana (simple cues) seperti agama, gender, suku, usia, wajah, dan penampilan kandidat seringkali digunakan oleh para pemilih sebagai penentu. Hal ini sering dilakukan bukan hanya oleh mereka yang berpendidikan rendah maupun kelas ekonomi bawah, namun juga oleh mereka yang berpendidikan dan berpenghasilan tinggi. Terutama pada pemilihan calon anggota legislatif.

Penelitian menemukan bahwa kesan pertama (first impression) dapat menimbulkan prediksi mengenai opini (Bar, Neta, \& Linz, 2006), 
membentuk kesan berikutnya, dan perilaku dari penerima impresi terhadap sang obyek (Rucker, Taber, \&\& Harrison, 1981). Bar dan rekannya (2006) menemukan bahwa impresi mengenai kepandaian tebentuk dalam 39 milisecond (ms) setelah terpaan, dan impresi secara keseluruhan terbentuk dalam $1700 \mathrm{~ms}$. Kesan pertama menjadi semakin penting mengingat betapa besar keyakinan seseorang terhadap kesan pertama yang diiliki terhadap orang lain, dan betapa hal tersebut sulit sekali diubah. Sebuah penelitian menemukan bahwa $77 \%$ partisipan berpendapat bahwa kesan pertama yang terbentuk berdasarkan cara mereka berpakaian, cukup akurat menggambarkan karakter orang tersebut. Ketika sebaliknya ditanyakan apakah penilaian yang dibentuk oleh orang lain berdasarkan cara berepakaian mereka, 69\% partisipan menilai akurat. Pengertian kesan pertama sendiri adalah momen di mana seseorang pada saat melihat atau bertemu dengan sosok orang lain dan membentuk imej mental (mental image) tentang orang tersebut (Mackie \& Smith, 2007).

Dalam pemilihan umum dengan tingkat informasi yang rendah (low information election) seperti pemilihan anggota legislatif, di mana banyak kandidat yang tidak dikenal dan diketahui visi misinya oleh para pemilih, apa yang ditampilkan dalam iklan atau foto dalam surat suara menjadi petunjuk utama bagi para pemilih.

Pada pemilu legislatif kita disodori begitu banyak calon anggota DPR, DPD, dan DPRD yang sebagian besar namanya belum pernah kita dengar dan wajahnya belum pernah kita lihat. Sehingga akhirnya pemilih mendasarkan pilihannya berdasarkan informasi berkualitas rendah, karena waktu ataupun sumber untuk mengenal lebih jauh rekam jejak dan kompetensi kandidat tidak tersedia.Penilaian singkat (quick judgement) dan kesan pertama yang timbul berdasarkan apa yang terlihat seringkali dirasa cukup bagi pemilih untuk menentukan pilihannya. Foto calon legislatif (caleg) yang tersebar di sepanjang jalan, jejaring sosial, media cetak, ataupun kertas suara dirasa cukup menjadi dasar pemilih untuk menjatuhkan pilihan.Kondisi ini merupakan tantangan bagi negara demokrasi manapun, tantangan bagi negara, masyarakat, serta kandidat yang berlaga di pemilu.

Dalam kondisi seperti ini, terdapat kondisi lain yang menyangkut keterlibatan perempuan dalam politik praktis. Persyaratankuota $30 \%$ bagi perempuan ditegaskan kembali oleh Mahkamah Konstitusi awal tahun ini. Hal ini jelas merupakan kabar baik bagi perempuan yang berniat untuk meraih kursi di pemilu legislatif mendatang, mengingat negara sekali lagi menegaskan peran perempuan dalam pembuatan kebijakan publik

Namun demikian, memenangkan suara rakyat tidaklah semudah membalikkan telapak tangan, munculnya politisi-politisi perempuan yang terjerat kasus korupsi, serta kurangnya pengetahuan politik para pemilih adalah tantangan yang harus dihadapi kaum perempuan yang berlaga di panggung ini. Dikatakan oleh pengamat politik I Nyoman Wiratmaja, modal intelektualitas tinggi yang dimiliki caleg perempuan tidak menjamin mereka dapat memenangkan "kompetisi" pada Pemilu 2014. "Oleh karena itu, masih perlu ada terobosan serius para caleg perempuan, bagaimana upaya mereka mengimbau pemilih perempuan dan meyakinkan bahwa sesungguhnya kaum hawa mempunyai nilai lebih dari sisisosial, perkembangan ekonomi kedepan, transparansi dan lebih bisa memanajemen konflik internal maupun eksternal. Itu harus dibuktikan. "(Metrobali.com, 2013).

Dunia politik saat ini yang semakin kaya dengan masuknya unsur marketing, membuat perdebatan mengenai ideologi menjadi sesuatu yang tidak lagi menarik. Party $I D$ semakin melemah, sehingga perilaku memilih yang berkembang adalah perilaku yang berorientasikan isu atau calon. Sistem pemilhan umum secara langsung membuat baik partai maupun pemilih memberi perhatian lebih kepada kandidat.

Kandidat yang memiliki tampilan, kemampuan, kepribadian, rekam jejak, dan kehidupan pribadi adalah produk politik yang lebih menarik dibandingkan sebuah partai. Perilaku memilih yang lebih memperhatikan kandidat dibandingkan partai pengusungnya bukanlah perilaku yang salah jika dibarengi dengan inisiatif pemilih untuk benarbenar mencaritahu informasi mengenai kapasitas dan kebijakan yang akan diusung kandidat sendainya ia menjabat.

Namun sekali lagipemilihan anggota legislatif tidak sama dengan pemilihan presdien, di mana kandidatnya telah dikenal oleh masyarakat. Ditambah sebagian besar pemilih di Indonesia jatuh ke dalam kategori low-information voters. Bukan hanya disebabkan oleh ketiadaan inisiatif dan waktu dari pemilih namun juga komunikasi yang kurang dari mereka yang ingin dipilih. Hal ini 
mengapa jalan-jalan pintas masih sering dilewati oleh kandidat dan pemilih.

Hasil survei nasional tentang iklan politik dan perilaku pemilih menjelang pemilu 2009 yang diadakan Puskapol UI menunjukkan sejumlah 42\% masyarakat mengaku belum pernah menerima program partai politik dan caleg. Hal ini cukup memprihatinkan mengingat waktu kampanye yang relatif panjang. Sementara sebagian mengaku sudah memperoleh informasi tentang program partai dan caleg (58\%).

Namun yang perlu menjadi catatan adalah bahwa mayoritas masyarakat mengatakan bahwa sumber informasi tentang partai politik dan caleg umumnya diperoleh melalui spanduk atau baliho (72\%) (Puskapol UI, 2009). Jadi komunikasi partai dengan masyarakat lebih banyak dilakukan melalui media tidak langsung seperti spanduk, poster, baliho, kartu nama, brosur, buletin dan souvenir kampanye lainnya. Dalam pola komunikasi yang demikian, penampilan kandidat menjadi hal yang penting baik bagi kandidat, tim suksesnya, maupun bagi pemilih.

Dalam iklim politik yang penuh dengan persaingan terbuka dan transparan, diperlukan suatu strategi untuk memenangkan persaingan politik. Kandidat membutuhkan suatu metode yang dapat memfasilitasi mereka dalam memasarkan inisiatif politik, gagasan politik, karakteristik, dan program kerjanya kepada masyarakat.

Seperti yang sudah disebutkan sebelumnya, tantangan ini semakin berat ketika sebagian besar profil pemilih di Indonesia adalah low-information voters yang sering kali mendasarkan pilihannya hanya pada sinyal atau informasi sederhana bersifat heuristik yang merekaterima. Mereka memilih berdasarkan rasa 'suka' (liking) yang timbul karena anggapan bahwa kandidat tersebut menarik (Samuel L, 1994). Kondisi ini membuat para kandidat seringkali justru terfokus pada strategi-strategi yang ingin menciptakan rasa suka secara instan.

Pada kandidat perempuan, terutama yang belum dikenal oleh para pemilih, menjadi perlu menemukan sebuah kemasan yang menggambarkan citra, posisi, dan kompetensi kandidat, dan juga mampu menarik pemilih. Tidak hanya jargon, pada akhirnya para kontestan politik ini memutar otak untuk menemukan cara yang dirasa efektif dalam menimbulkan citra positif mengenai dirinya yang dapat dilakukan dalam media dan waktu yang terbatas. Salah satu cara untuk menimbulkan kesan adalah melalui pakaian yang kita kenakan, tampaknya hal tersebut juga dipercayai oleh para calon legislatif perempuan. Sehingga tidak jarang ditemui seorang kandidat yang merubah penampilannya saat mencalonkan dirinya sebagai anggota legislatif.

Di Indonesia, perubahan yang paling mudah diamati dan kerap terjadi pada kandidat perempuan adalah penggunaan jilbab oleh mereka yang sebelumnya tidak berjilbab. Strategi ini dilakukan tidak hanya oleh kandidat yang tidak dikenal, namun juga yang sudah populer atau yang citranya telah terbentuk pada masyarakat. Seperti yang dilakukan oleh parakandidat dari kalangan selebritis layaknya Angel Lelga, Lyra Virna, ataupun Jane Shalimar yang sebelum mencalonkan diri, kerap mengenakan pakaian terbuka, bahkan menjadi model majalah dewasa, namun setelah menjadi calon legislatif mereka tampil dengan jilbab. Jane Shalimar yang merupakan caleg dari Partai Nasdem bahkan secara terbuka menyatakan pada wartawan, bahwa alasan awal ia menggunakan hijab adalah untuk kepentingan pencalegan (Merdeka.com, 2013).

Hubungan antara penampilan seorang politisi dan persepsi pemilih atau bahkan jumlah suara yang diperoleh merupakan kajian riset yang telah mencuri banyak perhatian di negara barat. Namun kajian ini belum banyak dikembangkan di Indonesia, sehingga apakah pemilih memang merasa kandidat yang berpakaian sopan atau muslimah dirasa lebih baik dari mereka yang tidak masih merupakan asumsi. Keputusan atau strategi pencitraan yang diambil para kandidat belum didasarkan pada bukti ilmiah. Hal ini menarik minat peneliti untuk mengetahui, apakah benar terdapat perbedaan persepsi di kalangan pemilih terhadap kandidat berjilbab dan tidak berjilbab. Di tengah maraknya kasus korupsi yang menyeret sederet wanita yang berjilbab, apakah stereotipe wanita berjilbab adalah wanita yang baik dan menjalani nilai-nilai agama juga berlaku pada wanita yang terjun ke dunia politik.

Diuraikan bahwa penampilan, khususnya penggunaan jilbab masih dipercaya oleh para calon anggota legislatif, sebagai strategi yang mampu mempengaruhi penilaian pemilih terhadap kandidat. Sementara belum ada bukti empiris yang menyatakan bahwa kandidat yang berjilbab dinilai lebih baik dari kandidat yang tidak berjilbab. Berdasarkan uraian tersebut dalam tulisan ini akan membahas tentang persepsi pemilih terhadap kandidat wanita berdasarkan penampilannya. 


\section{METODE}

Pada kajian inimenggunakanmetode studi eksperimental laboratorium, yaitu bertujuan untuk mengetahui hubungan sebab akibat, akibat dari penggunaan jilbab kandidat wanita terhadap hasil evaluasi kandidat oleh pemilih. Studi eksperimental adalah pendekatan tertua dalam penyelenggaran penelitian, yang kerap dilakukan dalam penelitian ilmu alam namun tidak lazim dilakukan pada permasalahan sosial. Namun demikian popularitas metode ini telah mengalami peningkatan popularitas dalam beberapa tahun terakhir (Kamhawi \& Weaver, 2003).

Studi eksperimental laboratorium memungkinkan adanya manipulasi variabel sebagai bentuk kontrol. Penerapan manipulasi sangat dibutuhkan dalam penelitian ini, terutama manipulasi terhadap kandidat wanita yang digunakan sebagai perlakuan atau treatment. Kajian menggunakan aktual kandidat, karena ditakutkan foto yang tersedia mengindikasikan afiliasi kandidat terhadap partai tertentu.Penulis mengadopsi beberapa langkah yang digunakan penelitian sebelumnya dan kriteria-kriteria yang digunakan dalam penelitian mengenai evaluasi kandidat di Amerika Serikat khususnya, mengingat penelitian dengan topik dan metode yang sama sulit ditemukan di Indonesia.

Penelitian menggunakan desain eksperimen faktorial $2 \times 2$. Faktor dalam penelitian ini merujuk pada jumlah variabel independen, dan penelitian yang melibatkan analisis terhadap dua atau lebih variabel independen disebut desain faktorial ( $f a c$ torial design). Desain faktorial mensyaratkan setidaknya ada 2 variabel independen yang akan diteliti. Desain penelitian 2 × 2 berarti penelitian ini memiliki 2 variabel independen, dengan dua level pada setiap variabel.

Penelitian ini ingin mempelajari pengaruh penampilan kandidat wanita terhadap persepsi pemilih. Subyek yang telah ditentukan secara random akan ditempatkan ke dalam empat kelompok. Kelompok I akan menerima treatment foto kandidat A menggunakan jilbab; Kelompok II menilai foto kandidat A tanpa jilbab; Kelompok III menilai foto kandidat B menggunakan jilbab; dan Kelompok IV menilai kandidat B tanpa jilbab.

Treatment yang digunakan dalam penelitian ini terbagi dalam dua kategori usia, yaitu kandidat muda dan kandidat tua. Hal ini dikarenakan semakin banyaknya caleg muda yang berlaga dalam pemilu. Dan peneliti merasa penting untuk memastikan ada atau tidaknya perbedaan persepsi para pemilih terhadap kandidat muda (A) dan tua (B) yang sekiranya mungkin mendistorsi analisis mengenai persepsi terhadap penggunaan jilbab dan tidak.

Respondendalamkajianiniberjumlah 40 mahasiswa S1. Dalam perekrutan partisipan, peneliti tidak memberikan syarat lain selain status partisipan sebagai mahasiswa S1.Jenis kelamin tidak menjadi persyaratan penting dalam penelitian ini, merujuk pada hasil penelitian terdahulu milik Shabad dan Andersen, yang menemukan bukti bahwa tidak ada perbedaan antara laki-laki dan wanita dalam mengevaluasi kandidat(Shabad \& Andersen, 1979).Dalam merekrut responden atau partisipan, peneliti menyebarkan pengumuman melalui media sosial path. Peneliti mengunggah foto yang berisi informasi mengenai kebutuhan responden untuk sebuah penelitian dalam akun path miliknya. Foto tersebut kemudian di unggah ulang (repath) oleh teman-teman peneliti, sehingga informasi tersebar luas dalam waktu singkat.

Menurut Wimmer dan Dominick, randomisasi adalah teknik yang sangat kuat untuk mengeliminasi pengaruh dari variabel-variabel lain di luar yang telah ditentukan (extraneous variable). Random dalam bahasa sehari-hari berarti tidak direncanakan, sedang dalam bahasa teori probabilitas, random mendeskripsikan sebuah proses di mana setiap kasus atau individu memiliki kesempatan yang sama untuk terpilih. Random assignment atau randomisasi berarti setiap subjek memiliki kesempatan yang sama untuk masuk dalam setiap kelompok eksperimen.

Random assignment merupakan salah satu unsur penting dalam penyelenggaraan eksperimen, agar peneliti dapat memberikan perlakuan yang ekuivalen terhadap setiap kelompok. Karena itu random assignment harus dilaksanakan dalam metode yang matematis, bukan berdasarkan preferensi peneliti.

Ada berbagai macam cara untuk melakukan random assignment. Cara-cara tersebut pada prakteknya cukup mudah dilakukan, seperti melempar koin, dadu, atau meminta para partisipan untuk berhitung. Proses random juga dilakukan untuk menjaga kesahihan penelitian ini. Memanfaatkan daftar hadir peserta sebagai kerangka sampel, peneliti menuliskan nomer 1 sampai dengan 51 pada sebuah kertas kecil untuk kemudia dilipat dan diambil secara random seperti 
pada acara undian.10 nomer pertama yang terambil, masuk ke dalam kelompok pertama. Kemudia peneliti kembali mengambil 10 nomer untuk dimasukkan ke kelompok kedua. Begitu seterusnya hingga tercipta 4 kelompok dengan masing-masing 10 nama partisipan.

Perlakuan atau treatment adalah variabel $\mathrm{X}$ yang telah mengalami manipulasi dan akan digunakan sebagai instrumen eksperimen. Perlakuan dalam penelitian ini adalah foto wanita yang diperankan sebagai calon legislatif. Foto yang ditampilkan tidak memberikan informasi apapun selain foto kandidat, yaitufotokandidat yang memakai jilbab danfotokandidat yang tidakmemakai jilbab. Tidak ada logo partai maupun nama kandidat.

Partisipan dalam penelitian ini diberikan informasi bahwa penelitian ini diadakan untuk mengetahui bagaimana pemilih membentuk penilaian terhadap kandidat politik. Keempat puluh partisipan akan dikelompokkan ke dalam empat kelompok, pemilihan kelompok ini dilakukan atas dasar hasil random assignment yang telah dilakukan sebelumnya.

Penelitian diselenggarakan dalam ruangan kelas yang dilengkapi dengan LCD proyektor dan perkiraan waktu yang dibutuhkan untuk melakukan eksperimen pada tiap kelompok adalah 10 menit. Setiap kelompok menerima treatment yang sama, mereka akan diperlihatkan satu foto kandidat selama 25 detik dan kemudian diminta mengisi kuisioner yang berisi pertanyaan mengenai karakteristik-karakteristik yang dirasa sesuai menggambarkan kandidat.

Tiap kelompok secara bergiliran memasuki ruangan, dan sebelum diperlihatkan foto kandidat, peneliti menginformasikan bahwa foto yang digunakan adalah foto seorang calon legislatif di suatu daerah. Namun peneliti tidak dapat memberikan informasi mengenai nama, partai, dan dapil caleg tersebut karena masalah privasi. Dengan demikian, partisipan tidak memperoleh informasi apapun kecuali foto kandidat.

\section{HASIL DAN PEMBAHASAN}

Berdasarkan uji komparatif Mann-Whitney yang dilakukan, hampir seluruhnya menunjukkan tidak ada perbedaan persepsi di kalangan pemilih terhadap kandidat yang berbeda secara penampilan, baik dalam hal pengunaan jilbab maupun usia.Pada uji beda berdasarkan penggunaan jilbab, dari 16 variabel yang diuji, perbedaan hanya nampak pada 2 variabel : pengalaman kandidat dan lamanya kandidat memperjuangkan kepentingan rakyat sebelum ia mencalonkan diri. Pada kriteria pengalaman kandidat, di mata pemilih kandidat berjilbab terlihat sebagai sosok yang lebih berpengalaman. Sementara kandidat tidak berjilbab terlihat kurang berpengalaman. Sementara pada variabel perjuangan kandidat, kandidat berjilbab dinilai telah memperjuangkan kepentingan rakyat dalam waktu yang lebih lama dibandingkan kandidat tidak berjilbab.

Hasil ini menarik, karena meskipun penggunaan jilbab adalah salah satu bentuk ketaatan pada norma agama, ternyata tidak membuat penggunanya dinilai lebih religius dibanding yang tidak memakainya. Pengguna jilbab juga tidak dipersepsikan lebih baik pada variabelvariabel yang berkaitan dengan moralitas seseorang seperti kejujuran dan ketulusan.

Berdasarkan 16 indikator yang dianalisis, semuanya menunjukkan nilai signifikansi yang mengindikasikan penolakan terhadapH1, artinya tidak ada perbedaaan persepsi di kalangan pemilih terhadap kandidat wanita berusia tua dan muda. Bahkan pada variabel pengalaman sekalipun, ternyata usia tidak dipandang sebagai petunjuk yang dapat mengindikasikan pengalaman kandidat tersebut di dunia politik. Hasil tersebut berbeda dengan temuan Efran dan Patterson (1976) yang menyatakan bahwa kandidat perempuan berusia tua dipersepsikan lebih baik dan lebih menarik minat pemilih ketimbang kandidat berusia muda.

Persepsipemilih sulit dilepaskan dari karakterisitik responden yaitu mahasiswa $\mathrm{S} 1$ yang diasumsikan sebagai individu-individu dengan tingkat NFC (need for cognition) tinggi yang menikmati aktivitas berfikir secara abstrak dan mendalam, sedang mereka yang tingkat NFCnya rendah beranggapan bahwa berfikir bukanlah sesuatu yang menyenangkan, dan mereka hanya akan berfikir sejauh yang mereka harus lakukan. Meski NFC tidak sama dengan intelejensia, namun seringkali keduanya berhubungan. Karena bagaimanapun juga seseorang membutuhkan tingkat intelejensia yang tinggi untuk menikmati isu-isu yang rumit.

Seseorang dengan tingkat NFC yang tinggi pada dasarnya sulit dipengaruhi oleh penampilan luar, oleh karena itu penampilan kandidat tidak menimbulkan perbedaan persepsi di kalangan 
Tabel 1. Hasil analisis persepsi responden terhadap penampilan kandidat calon legislatif yang berjilbab dan tidak berjilbab

\begin{tabular}{|c|c|c|c|}
\hline \multirow[b]{2}{*}{ No. } & \multirow[b]{2}{*}{ Indikator } & \multicolumn{2}{|c|}{ Persepsi Kandidat } \\
\hline & & $\begin{array}{c}\text { Kandidat Berjilbab } \\
\text { dan Tidak Berjilbab }\end{array}$ & $\begin{array}{l}\text { Kandidat Usia Tua } \\
\text { danMuda }\end{array}$ \\
\hline 1 & Religiusitas kandidat & Tidak ada perbedaan & Tidak ada perbedaan \\
\hline 2 & Keramahan kandidat & Tidak ada perbedaan & Tidak ada perbedaan \\
\hline 3 & $\begin{array}{l}\text { Kepedulian kandidat terhadap isu sos. } \\
\text { masyarakat di lingkungannya }\end{array}$ & Tidak ada perbedaan & Tidak ada perbedaan \\
\hline 4 & Tingkat Pendidikan & Tidak ada perbedaan & Tidak ada perbedaan \\
\hline 5 & $\begin{array}{l}\text { Kemampuan mengatasi isu perempuan } \\
\text { dan anak }\end{array}$ & Tidak ada perbedaan & Tidak ada perbedaan \\
\hline 6 & Kemampuan mengatasi masalah kemiskinan & Tidak ada perbedaan & Tidak ada perbedaan \\
\hline 7 & Tingkat Kepintaran & Tidak ada perbedaan & Tidak ada perbedaan \\
\hline 8 & Pengalaman kandidat di bidang politik & Ada perbedaan & Tidak ada perbedaan \\
\hline 9 & Reputasi kandidat & Tidak ada perbedaan & Tidak ada perbedaan \\
\hline 10 & $\begin{array}{l}\text { Lama kandidat memperjuangkan kepentingan } \\
\text { rakyat sebelum mencalonkan diri }\end{array}$ & Ada perbedaan & Tidak ada perbedaan \\
\hline 11 & Tingkat ketegasan kandidat & Tidak ada perbedaan & Tidak ada perbedaan \\
\hline 12 & $\begin{array}{l}\text { Kemampuan kandidat untuk melakukan } \\
\text { tindakan yang menginspirasi masyarakat }\end{array}$ & Tidak ada perbedaan & Tidak ada perbedaan \\
\hline 13 & $\begin{array}{l}\text { Tingkat etos kerja kandidat dalam } \\
\text { memperjuangkan kepentingan rakyat }\end{array}$ & Tidak ada perbedaan & Tidak ada perbedaan \\
\hline 14 & $\begin{array}{l}\text { Kehati-hatian kandidat dalam mengambil } \\
\text { tindakan }\end{array}$ & Tidak ada perbedaan & Tidak ada perbedaan \\
\hline 15 & Kejujuran kandidat & Tidak ada perbedaan & Tidak ada perbedaan \\
\hline 16 & $\begin{array}{l}\text { Tingkat ketulusan kandidat dalam } \\
\text { memperjuangkan kepentingan rakyat }\end{array}$ & Tidak ada perbedaan & Tidak ada perbedaan \\
\hline
\end{tabular}

responden. Besar kemungkinan bahwa para responden adalah mereka yang menikmati berfikir secara mendalam. Beranggapan bahwa menilai kandidat diperlukan informasi lebih dari sekedar gender, usia, dan gaya berpakaian kandidat.

Karakter responden masuk ke dalam generasi C, yaitugenerasi yang lahir antara tahun 1982 hingga 2001. Menurut Dr. Pankraz seorang ahli perencanaan dari perusahaan marketing di Australia, ada lima ciri anak muda generasi C, pertama adalah kecintaan terhadap kreasi dan penggabungan (creation and mashing), hal ini terlihat nyata pada industri film dan musik independen yang tubuh begitu pesat dan subur karena teknologi yang semakin mudah diakses dengan biaya yang semakin minimal, baik dalam produksi maupun pemasaran.Kedua, tendensi untuk membentuk komunikasi aktif. Hal ini adalah karakter yang timbul akibat sosial media, di mana siapapun semakin mudah dan lazim untuk menyatakan pemikirannya dan pendapatnya tentang apa saja. Ketiga, ketertarikan terhadap sosial media di mana mereka dapat berpartisipasi dalam diskusi tentang berbagai ide dan terlibat dalam obrolan budaya. Hal ini berimplikasi kepada peningkatan intelejensia dan penerimaan anak muda terhadap perbedaan. Mereka yang berbeda tidak lagi dianggap buruk.Keempat, keinginan untuk mengontrol kehidupan mereka, dan dipenuhi dengan kompleksitas. Terakhir adalah keinginan kuat untuk bekerja dalam industri kreatif dan tidak dibatasi oleh aturan sosial yang kaku.

Jika dilihat dari ciri di atas, terlihat bahwa anak muda saat ini cenderung lebih toleran dan tidak dibatasi oleh nilai dan aturan sosial. Keinginan untuk mengontrol hidupnya menjadikan pengalaman hidup sebagai acuan utama dalam kehidupan seharihari.Hal tersebut dapat menjelaskan mengapa atribut agama tidak lagi menjadi acuan kualitas moral seseorang, dan gaya berpakaian antara mereka yang berjilbab dan tidak tak lagi dipandang sebagai sesuatu yang membedakan.

Hal lain yang masih berkaitan dengan karakteristik responden adalah, penelitian ini 
dilakukan di Jakarta, kota metropolitan, dengan seluruh responden adalah mahasiswa perguruan tinggi di kota ini. Berbeda dengan karakteristik masyarakat pedesaan, masyarakat perkotaan cenderung kurang religius karena mereka mengedepankan pemikiran rasional, masyarakat kota cenderung menilai dan dinilai dari prestasinya (Parson, 1951). Peneliti melihat, pola pikir yang mengedepankan rasionalitas dan penilaian atas dasar prestasi membuat penilaian terhadap kandidat yang berjilbab maupun tidak, berusia muda dan tua, tidak jauh berbeda. Selai itu, kondisi kehidupan di kota besar di mana banyak sosok yang memakai atribut agama namun justru melanggar norma yang digariskan agama, menimbulkan sinisme tersendiri. Peneliti melihat adanya kemungkinan hasil yang berbeda jika penelitian dilakukan di kota lain, seperti kota yang lekat dengan tradisi pesantren seperti di Jember, Jawa Timur.

Alasan lain yang selain karakteristik responden namun juga masih berkaitan dengan desain penelitian ini adalah variasi treatment. Variasi penampilan yang diberikan dalam treatment sangatlah terbatas. Penelitian ini hanya memberikan dua bentuk variasi penampilan. Sementara cara seseorang memakai jilbab begitu beragam. Ada yang mengenakannya dengan menutup seluruh rambutnya, ada yang tidak. Ada yang mengulurkan jilbabnya hingga ke perut, ada yang sebatas leher. Variasi pemakaian jilbab ini juga berkaitan dengan beragamnya interpretasi ayat agar wanita muslim menutup auratnya, dan variasi ini dalam praktek sehari-hari sering diasosiasikan pula dengan penilaian apakah orang tersebut sudah berjilbab dengan baik dan benar. Selain cara memakai jilbab, pakaian kandidat pun sangatlah beragam ada yang menggunakan batik, baju formal, baju daerah, atasan berlengan panjang, pendek, dan lain sebagainya yang membuka kemungkinan adanya persepsi lain dari para pemilih.

Selain alasan-alasan yang berkaitan dengan karakteristik responden dan variasi treatment yang diberikan, terdapat alasan lain yang tidak berkaitan dengan desain penelitian. berikutnya adalah posisi fashion dalam dunia modern itu sendiri. Dalam buku Adorned in Dreams: Fashion and Modernity, fashion atau cara berpakaian seseorang itu ambivalen- karena saat kita mengenakan pakaian, kita menggambarkan sesuatu di atas tubuh kita dengan mengaburkan elemen seni, psikologi per- sonal, dan aturan sosial. Ambivalensi ini membingungkan dan menyiksa(Wilson, 1985). Namun fashion di sisi lain juga mendefinisikan dan mengatur, mentransformasikan sesuatu yang tidak diketahui menjadi diketahui.

Gaya berpakaian seseorang seringkali dikaitkan dengan karakter, gaya berpakaian dapat menunjukkan profesi pemakainya, gaya berpakaian seseorang sering menjadi acuan orang di sekitarnya mengenai status sosial pemakainya.

Dalam dunia posmodernisme, khususnya penganut teori interaksi simbolis telah memulai perhatiannya pada fashion dan penampilan sejak tahun 1960an. Pemikiran posmodernis mengenai fashion berkisar pada pemikiran besar dari Stone bahwa fashion sebagai perilaku kolektif (fashion as collective behaviour), dan bahwa fashion adalah simbol yang ambigu yang dapat menghasilkan keragaman konstruksi makna(Stone, 1962).

Kekuatan pasar berkontribusi dalam ketidakpastian ini dengan menawarkan obyek dan gambaran yang kompleks, serta mempromosikan ide mengenai gaya 'do-it-yourself'. Range pilihan yang ditawarkan industri fashion turut menyebabkan kebingungan dalam membatasi kekacauan (budaya). Budaya menjadi ambivalen, fashion masa kini mengirimkan pesan yang sifatnya kontradiktif dan membingungkan kepada individu-individu bukan hanya mengenai asal pemakainya, namun juga standar mengenai cara berpakaian yang baik dan mengapa.

Pada analisis level mikro, para individu inilah yang menjadi penentu pembentukan makna mengenai arti berbagai gaya berpakaian. Karena individu memiliki pemikiran dan nilai-nilainya sendiri, dunia moderen tidak lagi memiliki suatu pakem tentang gaya berpakaian yang baik dan mengapa. Individu secara umum menemui kesulitan untuk menilai baik buruknya pribadi seseorang berdasarkan penampilannya (Kaiser, Nagasawa, \& Hutton, 1991).

Hal tersebut menunjukkan bahwa meskipun jilbab adalah suatu kewajiban dalam agama Islam, namun pada kenyataannya tidak membuat responden yang mayoritas muslim memberikan penilaian yang lebih baik pada kandidat berjilbab. Bahkan pada indikator religiusitas sekalipun, ternyata kandidat berjilbab dan tidak berjilbab tidak dipersepsikan secara berbeda. Jika seseorang tidak berjilbab, kemungkinan besar dia tidak menganggap seseorang yang berjilbab lebih baik 
dari dirinya. Atau seseorang berjilbab yang berfikir yang dalam kesehariannya menemukan fakta bahwa simbol keagamaan seperti jilbab bukan jaminan kebaikan seseorang, juga belum tentu memberikan penilaian yang buruk bagi seseorang yang tidak berjilbab.

Faktor lain yang dirasa berpengaruh dalam menjelaskan temuan penelitian ini adalah, gender stereotipe. Pemilih dapat menggunakan jenis kelamin kandidat sebagai 'low-information shortcut' untuk memperkirakan pijakan kebijakan kandidat, (pemilih) juga dapat menggunakan karakter demografis lainnya atau partisanship untuk mengevaluasi kandidat politik(Popkin, 1991).

Berbagai penelitian mengenai kaitan gender dan perilaku pemilih telah dilakukan. Ada kubu yang berpendapat tidak ada pengaruh yang signifikan terhadap periaku pemilih yang disebabkan oleh gender, dan ada kubu yang berpendapat bahwa pemilih menggunakan jenis kelamin kandidat untuk membuat penilaian mengenai karakter kandidat, kepercayaan, dan posisi isu (Koch, 2000; Kahn, 1996). Sebagai contoh, pemilih menilai kandidat pria lebih baik dalam menghadapi masalah kriminal dan hubungan luar negeri, sedang kandidat wanita lebih baik dalam menolong masyarakat miskin dan melindungi hak - hak perempuan.

Mengaitkan hasil penelitian yang dilakukan dengan hasil penelitian terdahulu, peneliti melihat indikasi bahwa pada kandidat wanita, stereotipe gender berperan lebih kuat daripada faktor usia dan gaya berpakaian. Tentunya hal ini perlu pembuktian empiris melalui penelitian di masa datang.

Persepsipemilih juga berkaitandengan kondisi perpolitikan di Indonesiasaatini. Maraknya kasus korupsi yang melibatkan politisi-politisi wanita berjilbab, baik yang berposisi sebagai anggota legilatif seperti Wa Ode Nurhayati, maupun kepala daerah seperti Ratu Atut Chosiyah tak ayal menimbulkan sinisme politik di kalangan pemilih. Sinisme lain adalah sinisme terhadap anggota dewan itu sendiri, eksposure media tentang anggota DPR yang tertidur saat sidang, atau malah menonton video porno membuat tingkat kepercayaan masyarakat terhadap lembaga ini semakin buruk. Hal tersebut terlihat dari berbagai survei yang berkaitan dengan kepuasan atau kepercayaan masyarakat terhadap DPR. Salah satunya adalah survei nasional "Internet, Apatisme, dan Alienasi Politik" yang digelar
Indikator Politik Indonesia pada tahun 2013, yang menemukan 58 persen responden menyatakan tak percaya partai politik, disusul dengan responden yang tak percaya politisi, menteri-menteri, DPR, dan presiden (Merdeka.com, 2013). Survei lainnya adalah Survei Nasional yang dise-lenggarakan Pol-Tracking Institute, yang menyebut sebagian besar masyarakat tidak puas dengan kinerja Dewan Perwakilan Rakyat dan hanya 12 persen saja yang mengatakan kinerja DPR baik (Tempo.Co, 2013)

Kalau kata sinis atau cynic dalam bahasa Inggris, diartikan sebagai seseorang yang percaya bahwa motivasi perilaku manusia adalah kepentingan pribadi. Sinisme politik (political cynism) oleh Cappella dan Jamieson didefinisikan sebagai ketidakpercayaan yang digeneralisasi (berasal) dari perilaku tokoh-tokoh atau pemimpin tertentu, atau kelompok politik tertentu, sebagai gambaran proses politik secara keseluruhan. Proses atau sinisme politik ini memandang politik sebagai dunia yang akan mengkorupsi orang-orang yang terlibat di dalamnya dan melibatkan orang-orang korup untuk masuk di dalamnya (Cappella \& Jamieson, 1997). Sinisme ini tentu menjadi pekerjaan rumah bagi siapapun yang peduli akan jalannya demokrasi di negara ini. Karena jika terus menerus diacuhkan, sinisme ini akan berkembang menjadi apatisme yang pada akhirnya menggerus bukan hanya kepercayaan namun juga partisipasi publik.

Terkait dengan persepsi bahwa kandidat berjilbab lebih berpengalaman dan berjuang lebih lama dibandingkan yang tidak berjilbab, peneliti melihat hal ini juga lekat akan banyaknya politisi ataupun kepala daerah wanita berjilbab yang diekspos oleh media massa. Tidak perduli pemberitaan itu negatif ataupun positif, namun sosok Tri Rismaharini, Ratu Atut, Wa Ode Nurhayati, dan beberapa nama yang terangkat oleh media adalah sosok wanita berjilbab yang terjun ke dunia politik. Sehingga tampaknya image jilbab mulai melekat pada sosok politisi.

\section{SIMPULAN}

Penampilan kandidat menjadi satu-satunya petunjuk bagi pemilih untuk menyusun argumentasi, ternyata penggunaan jilbab mampu membuat pemakainya dipersepsikan lebih baik pada hal pengalaman kandidat dan lamanya sosok tersebut berjuang untuk rakyat sebelum mencalonkan diri. 
Namun tidak pada kriteria religiusitas ataupun kejujuran.

Sementara itu, jika dilihat dari faktor usia kandidat, ternyata pemilih justru tidak melihat adanya perbedaan kualitas antara kandidat berusia tua dan berusia muda.Dengan kata lain, jawaban dari pertanyaan penelitian ini adalah benar terdapat

\section{DAFTAR RUJUKAN}

US Politicians : Candidate traits and experience. (2011, 06 02). Dipetik 06

press.org/2011/06/02/section-2-candidate-traitsand-experience/

KBBI. (2014, April). Dipetik Juni 17, 2014, dari http://kbbi.web.id/.

ANES. (2012). ANES utilities guide to public opinion. Dipetik 12 11, 2013, dari American National Election Study: anes.com

Bar, M., Neta, M., \& Linz, H. (2006). Very first impressions. 269-278.

Brock, T. (1967). Communication discrepancy and intent to persuade as determinants of counterargument production. Journal of Experimental Social Psychology 3, 296309.

Cappella, J. N., \& Jamieson, K. H. (1997). Spiral of Cynicism: The Press and The Public Good. ISBN: 9780195090642.

Dictionary.com. (t.thn.). Dipetik 06 17, 2014, dari http://www.dictionary.com

Efran, M. E. (1976). The Politics of Appearance. Unpublished Manuscript. Toronto: Univeristy of Toronto.

Frenning, S. (2012). Samuel Frenning Attraction Theory. Dipetik 12 11, 2014, dari eFolio Quest: http://samuelfrenning.efoliomn.com

Gille-Knauf, T. R., \& Mittag, R. M. (2008). Smart and Sexy? Major and Clothing's Influence on Perceptions of Intelligence. UW-L Journal of Undergraduate Research XI , 1-9.

Leeper, M. S. (1991). The impact of prejudice on female candidates: An experimental look at voter inference. American Politics Quarterly 19, 248-261.

Mackie, E. R., \& Smith, D. M. (2007). Social psychology .

Merdeka.com. (2013, 07 23). Merdeka.com Politik. Dipetik 05 27, 2014, dari merdeka.com

Merriam-Webster. (2014). Dipetik 05 12, 2014, dari Merriam-Webster Inc: http:// www.merriam-webster.com/ perbedaan persepsi atau skor evaluasi kandidat berdasarkan penampilan kandidat. Dalam hal ini adalah penampilan berdasarkan penggunaan jilbab dan tidak, terhadap persepsi pemilih mengenai hal pengalaman kandidat dan lamanya kandidat berjuang untuk kepentingan rakyat sebelum ia terpilih.

Miller, W. E. (1996). The New American Voter. Cambridge: Harvard University Press.

Moore, D. W. (2004, Juli 28). "Values" Seen as Most Important Characteristic of Presidential Candidates. Dipetik 05 12, 2014, dari Gallup World Poll: http:// www.gallup.com

Neuman, W.Lawrnce. (2009). Social Research Methods : Qualitative and Quantitative. ISBN-10: 0205615961

Nimmo, D. (2000). Komunikasi Politik, Khalayak, dan Efek. Rosda Bandung.

Parson, T. (1951). The Social System. London: Routledge.

Perloff, R. M. (2010). The Dynamics of Persuasion 4th Edition. New York: Routledge.

Popkin, S. L. (1991). The Reasoning Voter: Communication and Persuasion in Presidential Campaigns. Chicago: University of Chicago Press.

Prasetia, H. (2010). Pakaian, Gaya, dan Identitas Perempuan Islam .. Identitas Perempuan Indonesia: Status, Pergeseran Relasi Gender, dan Perjuangan Ekonomi Politik.

Puskapol UI. (2009). Hasil Survei Nasional Tentang Iklan Politik dan Perilaku Memilih Menjelang Pemilu 2009. Dipetik 12 11, 2013, dari Puskapol UI: http:// www.puskapol.ui.ac.id

Ross, R. S. (1997). The Speechmaking Process 11th edition. Allyn \& Bacon.

Rucker, M., Taber, D., \&\& Harrison, A. (1981). Rucker, M., Taber, The effect of clothing variation on first impressions of female job applicants. 53-64.

Samuel L, P. (1994). The Reasoning Voter: Communication and Persuasion in Presidential Campaigns.

Shabad, G., \& Andersen, K. (1979). Candidate Evaluations by Men and Women. The Public Opinion Quarterly, Vol. 43, No. 1, 1835. 
Stone, G. P. (1962). Appearance and the Self. Human Behavior and Social Process, 86118.

Tempo.Co. (2013, 10). Tempo.co >> Politik. Dipetik 05 11, 2014, dari http:// www.tempo.co/read/news/2013/10/20/
078523122/Ini-Hasil-Survei-NasionalKinerja-Para-Menteri-SBY

Wasesa, S. A. (2011). Political Branding \& Public Relations. Jakarta: Gramedia.

Wilson, E. (1985). Adorned in Dreams: Fashion and Modernity. London: Virago Press. 